\title{
Kajian Kualitas Air Laut dan Indeks Pencemaran Berdasarkan Parameter Fisika-Kimia Di Perairan Distrik Depapre, Jayapura
}

\author{
Baigo Hamuna ${ }^{1}$, Rosye H.R. Tanjung ${ }^{2}$, Suwito ${ }^{3}$, Hendra K. Maury ${ }^{2}$ dan Alianto ${ }^{4}$ \\ 1Jurusan Ilmu Kelautan dan Perikanan, Universitas Cenderawasih; e-mail: bhamuna@yahoo.com.sg \\ 2Jurusan Biologi, Universitas Cenderawasih \\ 3Jurusan Kimia, Universitas Cenderawasih \\ 4Jurusan Perikanan, Universitas Papua
}

\begin{abstract}
ABSTRAK
Kondisi kualitas air suatu perairan yang baik sangat penting untuk mendukung kelulushidupan organisme yang hidup di dalamnya. Penentuan status mutu air perlu dilakukan sebagai acuan dalam melakukan pemantauan pencemaran kualitas air. Penelitian ini bertujuan untuk mengkaji status mutu air dan menentukan indeks pencemaran berdasarkan parameter fisika-kimia di perairan Distrik Depapre, Kabupaten Jayapura. Pengambilan sampel kualitas air dilakukan pada bulan Oktober 2017 di lima stasiun penelitian, kemudian hasilnya dibandingkan dengan baku mutu air laut untuk biota laut berdasarkan KEPMEN-LH No. 51 Tahun 2004. Hasil penelitian menunjukkan bahwa parameter yang masih sesuai baku mutu antara lain suhu, salinitas, sulfida dan kecerahan perairan, sedangkan parameter yang telah melampaui baku mutu antara lain $\mathrm{pH}$, ammonia total, nitrat dan fosfat. Berdasarkan hasil perhitungan indeks pencemaran menunjukkan bahwa perairan Distrik Depapre berada dalam kategori tercemar ringan hingga tercemar sedang.
\end{abstract}

Kata kunci: Baku Mutu, Indeks Pencemaran, Kualitas Air, Parameter Fisika-Kimia, Distrik Depapre

\begin{abstract}
Good water quality is extremely important to support life of organisms. The determination of water quality status was needed as reference to monitor water pollution. This study aimed to assess the status of water quality and determine pollution index based on physical-chemical parameters in the Depapre District waters, Jayapura Regency. Sampling was carried out in October 2017 across five research stations, then the results were compared with water quality standards based on KEPMEN-LH No. 51 Tahun 2004 for marine biotas. The results showed that the parameters in according to the quality standards are temperature, salinity, sulphide and water transparency, while those that have exceeded the quality standards are $\mathrm{pH}$, total ammonia, nitrate and phosphate. Based on the calculation of pollution index indicates that the Depapre District waters was in light pollution to medium categories.
\end{abstract}

Keywords: Depapre District, Physical-Chemical Parameters, Pollution Index, Standards, Water Quality

Citation: Hamuna, B., Tanjung, R.H.R, Suwito, Maury H.K. dan Alianto. (2018).Kajian Kualitas Air Laut dan Indeks Pencemaran Berdasarkan Parameter Fisika-Kimia Di Perairan Distrik Depapre, Jayapura. Jurnal Ilmu Lingkungan, 16(1), 35-43, doi:10.14710/jil.16.135-43

\section{Pendahuluan}

Wilayah pesisir merupakan wilayah yang penting ditinjau dari berbagai sudut pandang perencanaan dan pengelolaan. Transisi antara daratan dan lautan di wilayah pesisir telah membentuk ekosistem yang beragam dan sangat produktif serta memberikan nilai ekonomi yang luar biasa terhadap manusia. Sejalan dengan pertambahan penduduk dan peningkatan kegiatan pembangunan sosial-ekonomi, nilai wilayah pesisir terus bertambah. Konsekuensi dari tekanan terhadap pesisir adalah masalah pengelolaan yang timbul karena konflik pemanfaatan akibat dari berbagai kepentingan di wilayah tersebut. Berbagai kegiatan di sepanjang pesisir laut dan paradigma sebagian masyarakat pesisir, yang menganggap laut sebagai tempat pembuangan sampah. Menurut Siahainenia (2001) dalam Damaianto dan Masduqi (2014), akan dijumpai berbagai jenis sampah dan bahan pencemar di laut, hal tersebut tentu dapat mengakibatkan degradasi lingkungan di wilayah pesisir dan ekosistem di sekitarnya. Sehingga, masuknya zat-zat organik dan anorganik ke badan air secara berlebihan, berdampak buruk pada perairan laut dan menyebabkan penurunan kualitas air laut secara fisik, kimia dan biologi.

Berdasarkan Peraturan Pemerintah Republik Indonesia Nomor 19 Tahun 1999 tentang Pengendalian Pencemaran dan/atau Pengrusakan Laut bahwa pencemaran laut adalah masuknya atau dimasukkannya makhluk hidup, zat, energi, dan/atau 
komponen lain ke dalam lingkungan laut oleh kegiatan manusia sehingga kualitasnya turun sampai tingkat tertentu yang menyebabkan lingkungan laut tidak sesuai lagi dengan baku mutu dan/atau fungsinya. Bahan pencemar yang masuk ke wilayah pesisir dan laut bisa berasal dari berbagai sumber. Keadaan fisik bahan pencemar dari suatu sumber bisa berbeda dari sumber yang lain, dengan komposisi yang berbeda-beda pula. Dengan demikian dampak yang ditimbulkan terhadap lingkungan juga bervariasi. Status mutu suatu perairan merupakan tingkat kondisi mutu perairan yang menunjukkan kondisi cemar atau kondisi baik dalam waktu tertentu dengan membandingkan dengan baku mutu yang telah ditetapkan.

Wilayah perairan pesisir dan laut Kabupaten Jayapura termasuk dalam wilayah administrasi Provinsi Papua. Dalam perkembangannya, wilayah pesisir Kabupaten Jayapura mengalami pengembangan untuk berbagai macam kepentingan dan peruntukan, seperti kegiatan pelabuhan, pariwisata bahari, pemukiman dan maritim serta pengembangan budidaya laut dan perikanan. Aktivitas-aktivitas tersebut tentunya akan mempengaruhi kualitas wilayah pesisir. Permasalahan yang sangat dominan bagi wilayah pesisir, pantai dan laut adalah terjadinya pencemaran yang mengakibatkan terjadinya penurunan kualitas dan kuantitas sumberdaya pesisir dan laut. Penurunan kualitas air akan menurunkan daya guna, hasil guna, produktivitas, daya dukung dan daya tampung dari sumberdaya perairan yang pada akhirnya menurunkan kekayaan sumberdaya alam. Menurut Gholizadeh et al. (2016) bahwa setiap perubahan dalam ekosistem rentan akibat kegiatan antropogenik yang dapat membahayakan habitat ikan dan organisme air lainnya.

Masuknya pencemar organik dan anorganik ke badan air perairan pesisir pantai dapat menyebabkan kualitas perairan mengalami degradasi fungsi secara biologis. Potensi perairan pesisir pantai dan laut sebagai sumber pangan bagi masyarakat akan terganggu. Cukup tingginya aktivitas manusia yang ada di wilayah pesisir Kabupaten Jayapura dikhawatirkan akan memberikan dampak pencemaran terhadap kondisi kualitas perairan. Oleh karena itu, untuk melestarikan fungsi pesisir dan laut perlu dilakukan pengelolaan kualitas dan pengendalian pencemaran air laut untuk kepentingan sekarang dan mendatang serta keseimbangan ekologis. Untuk mewujudkan peningkatan pengelolaan kualitas air laut salah satunya diperlukan suatu kajian dan pemetaan terhadap kualitas air laut.

Penelitian ini bertujuan untuk mengetahui kualitas perairan Distrik Depapre, Kabupaten Jayapura yang hanya difokuskan pada konsentrasi beberapa parameter fisika dan kimia perairan yang tertera pada baku mutu air laut untuk biota laut dan untuk mengetahui status mutu kualitas air laut dengan menggunakan metode Indeks Pencemaran (IP) berdasarkan parameter tersebut. Hasil dari 36 penelitian ini diharapkan dapat memberikan informasi dasar dan output yang dapat bermanfaat bagi pemerintah daerah dan masyarakat umum, khususnya mengenai kualitas air laut sehingga dapat dijadikan sebagai masukan dalam pengelolaan wilayah pesisir Kabupaten Jayapura.

\section{Metode Penelitian}

Penelitian ini dilakukan pada bulan Oktober 2017 yang berlokasi di perairan Distrik Depapre, Kabupaten Jayapura, Provinsi Papua. Titik pengukuran dan pengambilan sampel air laut sebanyak 5 stasiun dengan karakteristik yang berbeda antar tiap stasiun, yaitu:

1) Perairan pantai wisata Harlem;

2) Perairan pesisir Kampung Tablasupa (pemukiman penduduk berada di perairan);

3) Perairan Pulau Dua;

4) Perairan lokasi pembangunan pelabuhan Depapre;

5) Perairan Kampung Depapre (pemukiman penduduk berada di daratan).

Pengukuran kualitas air laut secara insitu pada setiap stasiun dilakukan sebanyak 5 kali ulangan, dimana antara titik pengukuran berjarak 10 meter. Sedangkan untuk pengambilan sampel air laut yang memerlukan analisis laboratorium dilakukan dengan memasukkan sampel air laut ke dalam botol Niskin dan disimpan dalam coolbox untuk dianalisis di Laboratorium Ilmu kelautan dan Perikanan, Universitas Cenderawasih (Lab. IKL) dan Laboratorium Kesehatan Daerah Kota Jayapura (Lab. KESDA). Adapun jenis parameter fisika dan kimia air laut yang diuji dalam penelitian ini, serta metode pengukuran dan standar analisis yang digunakan disajikan pada Tabel 1.

Analisis data hasil pengukuran insitu dan hasil analisis laboratorium parameter kualitas air dilakukan secara deskriptif, yaitu dengan membandingkan hasil yang diperoleh dengan baku mutu kualitas air laut untuk biota laut berdasarkan Keputusan Menteri Lingkungan Hidup Nomor 51 Tahun 2004 tentang Baku Mutu Air Laut, yang diantaranya dikhususkan untuk kehidupan biota laut.

Penentuan status pencemaran ditentukan dengan mengggunakan indeks pencemaran menurut Sumiotomo dan Nerow (1970) dalam Keputusan Menteri Negara Lingkungan Hidup Nomor 51 Tahun 2004 sebagai berikut.

$$
P I_{j}=\sqrt{\frac{\left(C_{i} / L_{i j}\right)_{M}^{2}+\left(C_{i} / L_{i j}\right)_{R}^{2}}{2}}
$$

Dimana:
$\mathrm{L}_{\mathrm{i}}$
: Konsentrasi parameter kualitas air dalam baku mutu peruntukan air (j)
$\mathrm{C}_{\mathrm{i}} \quad$ : Konsentrasi parameter kualitas air hasil survei
$\mathrm{PI}_{\mathrm{j}} \quad$ : Indeks pencemaran bagi peruntukan (j) 
Hamuna, B., Tanjung, R.H.R, Suwito, Maury H.K., Alianto. (2018). Kajian Kualitas Air Laut dan Indeks Pencemaran Berdasarkan Parameter Fisika-Kimia Di Perairan Distrik Depapre, Jayapura. Jurnal IImu Lingkungan, 16(1), 35-43, doi:10.14710/jil.16.1.35-43

$\left(\mathrm{C}_{\mathrm{i}} / \mathrm{L}_{\mathrm{ij}}\right)_{\mathrm{M}}:$ Nilai $\mathrm{C}_{\mathrm{i}} / \mathrm{L}_{\mathrm{ij}}$ Maksimum

$\left(\mathrm{C}_{\mathrm{i}} / \mathrm{L}_{\mathrm{ij}}\right)_{\mathrm{R}}$ : Nilai $\mathrm{C}_{\mathrm{i}} / \mathrm{L}_{\mathrm{ij}}$ Rata-rata

1. $0 \leq \mathrm{PI}_{\mathrm{j}} \leq 1,0 \quad$ : Memenuhi baku mutu

Adapun hubungan tingkat ketercemaran dengan

kriteria indeks pencemaran berdasarkan Keputusan Menteri Negara Lingkungan Hidup Nomor 115 Tahun 2003 tentang Penetapan Status Mutu Air sebagai

2. $1,0<\mathrm{PI}_{\mathrm{j}}<5,0$ : Tercemar ringan

3. $5,0<\mathrm{PI}_{\mathrm{j}} \leq 10$ : Tercemar sedang

4. $\mathrm{PI}_{\mathrm{j}}>10$

: Tercemar berat

Tabel 1. Parameter dan metode analisis kualitas air laut

\begin{tabular}{lll}
\hline \hline Parameter & Tipe Analisis & Spesifikasi Alat/Metode Analisis \\
\hline Parameter Fisika: & Insitu & Secchi disk \\
Kecerahan & Insitu & Thermometer digital \\
Suhu & & \\
Parameter Kimia: & Insitu & Refraktometer \\
Salinitas & Insitu & pH meter \\
pH & Insitu & DO meter \\
Dissolved Oxygen $(\mathrm{DO})$ & Lab. IKL & Lovibond OxiDirect/Manometric \\
Biochemical Oxygen Demand $\left(\mathrm{BOD}_{5}\right)$ & Lab. KESDA & SNI 19-6964.3-2003 \\
Ammonia Total $\left(\mathrm{NH}_{3}-\mathrm{N}\right)$ & Lab. KESDA & SNI 19-6964.7-2003 \\
Nitrat $\left(\mathrm{NO}_{3}-\mathrm{N}\right)$ & Lab. KESDA & Standard Method 2005, Section 4500-P.C \\
Fosfat $\left(\mathrm{PO}_{4}-\mathrm{P}\right)$ & Lab. KESDA & SNI 19-6964.4-2003 \\
Sulfida $\left(\mathrm{H}_{2} \mathrm{~S}\right)$ & & \\
\hline
\end{tabular}

\section{Hasil dan Pembahasan}

Kualitas air laut yang digunakan untuk biota laut dan aktivitas lain secara ideal harus memenuhi standar, baik secara fisik, kimia, dan biologi. Nilai kualitas perairan laut yang melampaui ambang batas maksimum untuk peruntukannya akan digolongkan sebagai perairan tercemar. Adapun hasil pengukuran lapangan dan hasil analisis laboratorium terhadap kualitas beberapa parameter fisika dan kimia perairan Distrik Depapre, Kabupaten Jayapura disajikan pada Tabel 2 sebagai berikut.

Tabel 2. Hasil pengukuran dan analisis kualitas fisika dan kimia air laut perairan Depapre

\begin{tabular}{|c|c|c|c|c|c|c|c|}
\hline \multirow{2}{*}{ Parameter } & \multirow{2}{*}{ Satuan } & \multirow{2}{*}{ Baku Mutu1) } & \multicolumn{5}{|c|}{ Rata-Rata Hasil Pengukuran/Analisis2) } \\
\hline & & & St.1 & St.2 & St.3 & St. 4 & St. 5 \\
\hline \multicolumn{8}{|l|}{ Parameter Fisika } \\
\hline Kecerahan & $\mathrm{m}$ & $\begin{array}{c}\text { Coral: }>5 \\
\text { Mangrove: - } \\
\text { Lamun: }>3\end{array}$ & 13 & 13 & 9 & 12 & 2 \\
\hline Suhu & ${ }^{\circ} \mathrm{C}$ & $\begin{array}{c}\text { Coral: } 28-30 \\
\text { Mangrove: } 28-32 \\
\text { Lamun: } 28-30\end{array}$ & 29,7 & 29,4 & 29,2 & 29,2 & 29,4 \\
\hline \multicolumn{8}{|l|}{ Parameter Kimia } \\
\hline Salinitas & $\%$ & $\begin{array}{c}\text { Coral: } 33-34 \\
\text { Mangrove: s/d } 34 \\
\text { Lamun: } 33-34\end{array}$ & 33 & 34 & 34 & 34 & 30 \\
\hline $\mathrm{pH}$ & - & $7-8,5$ & 6,58 & 6,7 & 6,72 & 7,13 & 6,9 \\
\hline Dissolved Oxygen (DO) & $\mathrm{mg} / \mathrm{l}$ & $>5$ & 5,6 & 5,6 & 5,3 & 5,5 & 5,1 \\
\hline $\begin{array}{l}\text { Biochemical Oxygen Demand } \\
\left(\mathrm{BOD}_{5}\right)\end{array}$ & $\mathrm{mg} / \mathrm{l}$ & 20 & 8 & 9 & 10 & 8 & 13 \\
\hline $\begin{array}{l}\text { Ammonia Total } \\
\left(\mathrm{NH}_{3}-\mathrm{N}\right)\end{array}$ & $\mathrm{mg} / \mathrm{l}$ & 0,3 & 11,6 & 10 & 0,8 & 10 & 11,4 \\
\hline Fosfat $\left(\mathrm{PO}_{4}-\mathrm{P}\right)$ & $\mathrm{mg} / \mathrm{l}$ & 0,015 & 1,19 & 0,17 & 0,06 & 0,34 & 0,31 \\
\hline Nitrat $\left(\mathrm{NO}_{3}-\mathrm{N}\right)$ & $\mathrm{mg} / \mathrm{l}$ & 0,008 & 0,54 & 0,009 & 0,037 & 0,179 & 0,19 \\
\hline Sulfida $\left(\mathrm{H}_{2} \mathrm{~S}\right)$ & $\mathrm{mg} / \mathrm{l}$ & 0,01 & 0,003 & 0,003 & 0,003 & 0,003 & 0,003 \\
\hline
\end{tabular}

Sumber: ${ }^{1) K e p u t u s a n}$ Menteri Lingkungan Hidup Nomor 51 tahun 2004; ${ }^{2}$ Analisis data tahun 2017

\subsection{Kecerahan Perairan}

Kecerahan merupakan tingkat transparansi perairan yang dapat diamati secara visual menggunakan secchi disk. Dengan mengetahui kecerahan suatu perairan kita dapat mengetahui sampai dimana masih ada kemungkinan terjadi proses asimilasi dalam air, lapisan-lapisan mana yang tidak keruh, dan yang paling keruh. Perairan yang memiliki nilai kecerahan rendah pada waktu cuaca yang normal dapat memberikan suatu petunjuk atau indikasi banyaknya partikel-partikel tersuspensi dalam perairan tersebut. 
Berdasarkan hasil pengamatan, secara umum tingkat kecerahan perairan laut Depapre masih tergolong baik, dengan tingkat kecerahan air laut berkisar antara 2 - 13 meter. Sebagian besar hasil pengamatan masih di atas baku mutu air laut untuk biota laut dalam Keputusan Menteri Negara Lingkungan Hidup No. 51 tahun 2004, kecuali pada stasiun 5 (perairan Kampung Depapre) dengan tingkat kecerahan hanya 2 meter dan berada dibawah nilai baku mutu kualitas air laut, dimana pada stsiun 5 tersebut tidak terdapat karang dan lamun, dan didominasi oleh substrat lumpur. Rendahnya tingkat kecerahan pada stasiun 5 disebabkan karena banyaknya suplai sedimen dan partikel yang terlarut, bahan organik dan anorganik melalui aliran run off dari daratan dan menyebabkan tingkat kekeruhan perairan yang tinggi. Menurut Davis (1995) dalam Widiadmoko, (2013), kemampuan cahaya matahari untuk menembus sampai ke dasar perairan dipengaruhi oleh kekeruhan (turbidity) air. Oleh karena itu, tingkat kecerahan dan kekeruhan air laut sangat berpengaruh pada pertumbuhan biota laut. Tingkat kecerahan air laut sangat menentukan tingkat fotosintesis biota yang ada di perairan laut.

\subsection{Suhu Perairan}

Suhu perairan merupakan salah satu faktor yang amat penting bagi kehidupan organisme di perairan. Suhu merupakan salah satu faktor eksternal yang paling mudah untuk diteliti dan ditentukan. Aktivitas metabolisme serta penyebaran organisme air banyak dipengaruhi oleh suhu air (Nontji, 2005). Suhu juga sangat berpengaruh terhadap kehidupan dan pertumbuhan biota air, suhu pada badan air dipengaruhi oleh musim, lintang, waktu dalam hari, sirkulasi udara, penutupan awan dan aliran serta kedalaman air. Suhu perairan berperan mengendalikan kondisi ekosistem perairan. Peningkatan suhu menyebabkan peningkatan dekomposisi bahan organik oleh mikroba (Effendi, 2003). Kenaikan suhu dapat menyebabkan stratifikasi atau pelapisan air, stratifikasi air ini dapat berpengaruh terhadap pengadukan air dan diperlukan dalam rangka penyebaran oksigen sehingga dengan adanya pelapisan air tersebut di lapisan dasar tidak menjadi anaerob. Perubahan suhu permukaan dapat berpengaruh terhadap proses fisik, kimia dan biologi di perairan tersebut (Kusumaningtyas et al., 2014).

Hasil pengukuran suhu permukaan laut langsung secara langsung di lapangan (insitu), diperoleh bahwa suhu perairan Depapre yang relatif sama yaitu berkisar antara $29,2-29,7^{\circ} \mathrm{C}$. Keadaan suhu perairan yang diperoleh cenderung relatif sama antar stasiun pengamatan. Pada umumnya suhu permukaan perairan adalah berkisar antara $28-31^{\circ} \mathrm{C}$ (Nontji, 2005). Kisaran suhu hassil pengukuran tersebut juga masih dalam kisaran nilai suhu permukaan laut bulanan di perairan Jayapura yang berkisar antara 25 $-31^{\circ} \mathrm{C}$ dengan suhu dominan berkisar antara antara $27-29^{\circ} \mathrm{C}$ (Hamuna et al., 2015).

38
Berdasarkan baku mutu air laut untuk biota laut dalam Keputusan Menteri Negara Lingkungan Hidup No. 51 tahun 2004, maka suhu perairan laut Depapre masih berada dalam batas normal dan sesuai dengan kebutuhan untuk metabolisme biota laut dan ekosistem pesisir laut seperti karang, lamun dan mangrove.

\subsection{Salinitas}

Salinitas adalah konsentrasi seluruh larutan garam yang diperoleh dalam air laut, dimana salinitas air berpengaruh terhadap tekanan osmotik air, semakin tinggi salinitas maka akan semakin besar pula tekanan osmotiknya (Gufran dan Baso, 2007 dalam Widiadmoko, 2013). Perbedaan salinitas perairan dapat terjadi karena adanya perbedaan penguapan dan presipitasi.

Hasil pengukuran salinitas di perairan laut Depapre tidak terlalu berbeda jauh antar stasiun pengamatan $(30-34 \%$ ) dan dapat dikatakan bahwa nilai yang didapatkan bersifat heterogen dengan variasi nilai yang tidak terlalu besar kecuali salinitas pada stasiun 5. Nilai salinitas tersebut tidak berbeda jauh dengan nilai salinitas perairan Indonesia, dimana secara umum permukaan perairan Indonesia ratarata berkisar antara 32 - 34\%o (Dahuri et al., 1996).

Rendahnya salinitas pada stasiun 5 (perairan Kampung Depapre) disebabkan karena adanya suplai air tawar melalui aliran sungai yang bermuara di perairan laut. Seiring dengan pendapat Hutabarat dan Evans (1984) bahwa daerah estuaria adalah daerah dimana kadar salinitasnya berkurang karena adanya pengaruh air tawar yang masuk dan juga disebabkan oleh terjadinya pasang surut di daerah itu. Keragaman salinitas dalam air laut akan mempengaruhi jasadjasad hidup akuatik berdasarkan kemampuan pengendalian berat jenis dan keragaman tekanan osmotik. Berdasarkan baku mutu air laut dalam Keputusan Menteri Negara Lingkungan Hidup No. 51 tahun 2004, sebagian besar nilai salinitas pada stasiun pengamatan masih sesuai dengan baku mutu air laut untuk biota laut. Salinitas pada stasiun 5 lebih rendah dari baku mutu dan tidak bisa untuk pertumbuhan biota laut secara optimal, seperti karang dan lamun serta kegiatan budidaya biota laut, namun masih sesuai untuk pertumbuhan mangrove.

\section{4. pH (Derajat Keasaman)}

Derajat keasaman $(\mathrm{pH})$ merupakan logaritma negatif dari konsentrasi ion-ion hidrogen yang terlepas dalam suatu cairan dan merupakan indikator baik buruknya suatu perairan. $\mathrm{pH}$ suatu perairan merupakan salah satu parameter kimia yang cukup penting dalam memantau kestabilan perairan (Simanjuntak, 2009). Variasi nilai pH perairan sangat mempengaruhi biota di suatu perairan. Selain itu, tingginya nilai pH sangat menentukan dominasi fitoplankton yang mempengaruhi tingkat produktivitas primer suatu perairan dimana keberadaan fitoplankton didukung oleh 
Hamuna, B., Tanjung, R.H.R, Suwito, Maury H.K., Alianto. (2018). Kajian Kualitas Air Laut dan Indeks Pencemaran Berdasarkan Parameter Fisika-Kimia Di Perairan Distrik Depapre, Jayapura. Jurnal IImu Lingkungan, 16(1), 35-43, doi:10.14710/jil.16.1.35-43

ketersediaanya nutrien di perairan laut (Megawati et al., 2014).

$\mathrm{pH}$ perairan depapre hasil pengukuran relatif lebih rendah bila dibandingkan dengan $\mathrm{pH}$ hasil dari beberapa penelitian di perairan Papua. Misalnya hasil penelitian Erari et al. (2012) yang mendapatkan pH perairan Teluk Youtefa yang berkisar antara 6,28 - 8,7 di bagian laut dan 7,25 - 7,76 di perairan dekat muara sungai, serta Silalahi et al. (2017) yang mendapatkan pH perairan Maruni Manokwari berkisar antara 7 8,3. Menurtu Dojlido dan Best (1993) bahwa pH air laut relatif lebih stabil dan biasanya berada dalam kisaran 7,5 dan 8,4, kecuali dekat pantai. Nilai pH yang ideal bagi perairan adalah $7-8,5$. Kondisi perairan yang sangat basa maupun sangat asam akan membahayakan kelangsungan hidup organisme karena akan mengganggu proses metabolisme dan respirasi.

Berdasarkan Keputusan Menteri Negara Lingkungan Hidup No. 51 tahun 2004, pH perairan Depapre lebih rendah dari baku mutu yang dianjurkan untuk biota laut (kecuali stasiun 4). Rendahnya pH hasil pengukuran dapat saja terjadi karena $\mathrm{pH}$ di suatu perairan dipengaruhi oleh beberapa faktor antara lain aktivitas fotosintesa biota laut, suhu dan salinitas perairan. Kisaran $\mathrm{pH}$ hasil pengukuran yang diperoleh tersebut masih dapat ditolerir karena memiliki selisih yang cukup kecil dari baku mutu minimum yaitu sekitar 0,1 - 0,42. Selain itu, menurut Odum (1971) bahwa nilai pH antara 6,5 - 8,0 sebagai batas aman $\mathrm{pH}$ perairan untuk kehidupan biota di dalamnya.

\subsection{Dissolved Oxygen (D0)}

Oksigen terlarut (Dissolved Oxygen/DO) adalah total jumlah oksigen yang ada (terlarut) di air. DO dibutuhkan oleh semua jasad hidup untuk pernapasan, proses metabolisme atau pertukaran zat yang kemudian menghasilkan energi untuk pertumbuhan dan pembiakan. Disamping itu, oksigen juga dibutuhkan untuk oksidasi bahan-bahan organik dan anorganik dalam proses aerobik. Umumnya oksigen dijumpai pada lapisan permukaan karena oksigen dari udara di dekatnya dapat secara langsung larut berdifusi ke dalam air laut (Hutabarat dan Evans, 1985). Kebutuhan organisme terhadap oksigen terlarut relatif bervariasi tergantung pada jenis, stadium dan aktifitasnya (Gemilang et al., 2017).

Hasil pengukuran DO pada stasiun pengamatan cukup bervariasi berkisar antara 5,1 - 5,6 mg/l. Pada setiap stasiun pengambilan data, nilai DO yang diperoleh menandakan perairan dalam kondisi sangat baik, dan masih memenuhi standar baku mutu air laut dalam Keputusan Menteri Negara Lingkungan Hidup No. 51 tahun 2004 untuk kehidupan biota laut dengan nilai DO $>5 \mathrm{mg} / \mathrm{l}$, sehingga konsentrasi DO di perairan Depapre masih tergolong masih sesuai untuk biota laut. DO perairan Depapre bisa dikatakan masih lebih baik untuk mendukung kehidupan biota laut dimana pada setiap stasiun pengamatan masih memenuhi baku mutu bila dibandingkan dengan hasil penelitian di perairan Papua yang dilaporkan oleh Erari et al.
(2012) dan Silalahi et al. (2017) dimana pada beberapa stasiun pengamatan menunjukkan konsentrasi DO perairan laut di bawah baku mutu untuk biota laut.

Menurut Subarijanti (2005) dalam Kadim et al. (2017), kandungan oksigen dalam air yang ideal adalah antara $3-7 \mathrm{mg} / \mathrm{l}$. Konsentrasi DO yang lebih tinggi pada stasiun 1 dan $2(5,6 \mathrm{mg} / \mathrm{l})$ kemungkinan disebabkan karena pada kedua stasiun pengukuran tersebut terdapat biota vegetasi laut (lamun) yang cukup banyak. Kondisi tersebut sesuai dengan pernyataan Salmin (2005) bahwa sumber utama oksigen dalam suatu perairan berasal hasil fotosintesis organisme yang hidup dalam perairan tersebut, selain dari proses difusi dari udara bebas. Kandungan DO pada suatu perairan sangat berhubungan dengan tingkat pencemaran, jenis limbah dan banyaknya bahan organik di suatu perairan. Oleh karena itu, berdasarkan konsentrasi DO yang diperoleh, maka dapat disimpulkan bahwa dari nilai DO perairan laut Depapre tergolong dalam kategori tingkat pencemaran rendah dengan nilai DO $>5$ mg/l (Wirosarjono, 1974 dalam Salmin, 2005).

\subsection{Biochemical Oxygen Demand (BOD 5 )}

Biochemical Oxygen Demand (BOD) merupakan suatu karakteristik yang menunjukkan jumlah oksigen terlarut yang diperlukan oleh mikroorganisme untuk mengurai atau mendekomposisi bahan organik dalam kondisi aerobik. BOD adalah angka indeks untuk tolak ukur pencemar dari limbah yang berada dalam suatu perairan. Makin besar kosentrasi BOD suatu perairan, menunjukan konsentrasi bahan organik di dalam air juga tinggi (Yudo, 2010).

Hasil pengukuran $\mathrm{BOD}_{5}$ (sekitar 70 - 80\% dari nilai BOD total) pada stasiun pengamatan berkisar 8 $13 \mathrm{mg} / \mathrm{l}$. Nilai $\mathrm{BOD}_{5}$ yang diperoleh masih berada dibawah standar maksimum BOD $_{5}$ yang dianjurkan untuk biota laut dalam Keputusan Menteri Negara Lingkungan Hidup No. 51 tahun 2004 untuk kehidupan biota laut dengan nilai maksimal $20 \mathrm{mg} / \mathrm{l}$. $\mathrm{BOD}_{5}$ perairan Depapre masih dalam keadaan normal bila dibandingkan dengan $\mathrm{BOD}_{5}$ di perairan Teluk Youtefa Tayapura yang telah melebihi baku mutu $\mathrm{BOD}_{5}$ di perairan, yaitu lebih dari $27 \mathrm{mg} / \mathrm{L}$ di perairan muara sungai dan sekitar $270 \mathrm{mg} / \mathrm{l}$ di perairan laut Teluk Youtefa (Erari et al., 2012).

Parameter BOD merupakan parameter umum yang dapat digunakan untuk menentukan tingkat pencemaran air dari suatu sumber pencemaran. Berdasarkan kriteria tingkat pencemaran dari nilai $\mathrm{BOD}_{5}$, maka perairan laut Depapre tergolong dalam tingkat pencemaran rendah hingga sedang. Semakin tingginya konsentrasi BOD mengindikasikan bahwa peraian tersebut telah tercemar, sedangkan konsentrasi BOD yang tingkat pencemarannya masih rendah dan dapat dikategorikan sebagai perairan yang baik. Tingkat pencemaran rendah jika nilai BOD $_{5}$ 0 - $10 \mathrm{mg} / \mathrm{l}$, sedangkan tingkat pencemaran sedang jika nilai $\mathrm{BOD}_{5} 10$ - 20 mg/l (Salmin, 2005). 


\subsection{Ammonia Total $\left(\mathrm{NH}_{3}-\mathrm{N}\right)$}

Limbah merupakan salah satu masalah yang harus ditangani dengan baik karena limbah dapat mengandung bahan kimia yang berbahaya dan beracun. Salah satu bahan kimia yang umum terkandung dalam limbah adalah ammonia $\left(\mathrm{NH}_{3}\right)$ (Bonnin et al., 2008). Kadar ammonia dalam air laut sangat bervariasi dan dapat berubah secara cepat. Ammonia dapat bersifat toksik bagi biota jika kadarnya melebihi ambang batas maksimum.

Hasil analisis menunjukkan bahwa konsentrasi ammonia total di perairan laut Depapre dari hasil analisis berkisar 0,8 - 11,6 mg/l. Berdasarkan standar baku mutu ammonia total dalam untuk biota laut Keputusan Menteri Negara Lingkungan Hidup No. 51 tahun 2004, maka konsentrasi ammonia total di perairan Depapre sudah melebihi standar standar baku mutu ammonia total di perairan laut yang dianjurkan sebesar $0,3 \mathrm{mg} / \mathrm{l}$ untuk biota laut. Sebagaimana diketahui bahwa ammonia merupakan salah satu parameter pencemaran organik di perairan, jika konsentrasi ammonia di perairan terdapat dalam jumlah yang terlalu tinggi dapat diduga adanya pencemaran (Alarest dan Sartika (1987) dalam Widiadmoko (2013). Berdasarkan hasil analisis, hanya pada stasiun 3 yang memiliki konsentrasi ammonia total yang tergolong rendah dibandingkan stasiun lainnya. Hal ini dapat saja disebabakn karena posisi stasiun 3 yang sedikit lebih jauh dari wilayah pesisir. Apabila dibandingkan dengan konsentrasi ammonia total di perairan lain di Papua, maka didapatkan hasil yang relatif sama dengan konsentrasi ammonia total di perairan Teluk Youtefa Jayapura yang berkisar antara 0,5 - 16,1 di perairan laut dan 1,2 - 10,1 di sekitar muara sungai (Erari et al., 2012), serta lebih tinggi dibandingkan di perairan Maruni Manokwari yang berkisar antara 0,1 - 2,4 $\mathrm{mg} / \mathrm{l}$ (Silalahi et al., 2017).

Tingginya konsentrasi ammonia total di perairan Depapre sebagian besar diduga berasal dari limbah pemukiman dan pembuangan manusia dan hewan dalam bentuk urin, dimana pemukiman penduduk sebagian besar berada di wilayah pesisir dan laut. Selain itu, secara alami senyawa ammonia di perairan juga dapat berasal dari hasil metabolisme hewan dan hasil proses dekomposisi bahan organik oleh bakteri. Kadar ammonia yang tinggi dapat diindikasikan adanya pencemaran bahan organik yang berasal dari limbah domestik, limbah industri, maupun limpasan pupuk pertanian (Effendi, 2003). Lebih lanjut menurut Effendi (2003) bahwa sumber ammonia di perairan adalah hasil pemecahan nitrogen organik (protein dan urea) dan nitrogen anorganik yang terdapat dalam air, juga berasal dari dekomposisi bahan organik (tumbuhan dan biota akuatik yang telah mati) yang dilakukan oleh mikroba dan jamur. Lebih lanjut menurut Effendi (2003), meningkatnya kadar ammonia di laut berkaitan erat dengan masuknya bahan organik yang mudah terurai (baik yang mengandung unsur nitrogen maupun tidak).

\subsection{Fosfat $\left(\mathrm{PO}_{4-\mathrm{P}} \mathrm{P}\right)$}

Fosfat $\left(\mathrm{PO}_{4}-\mathrm{P}\right)$ merupakan salah satu unsur esensial bagi metabolisme dan pembentukan protein. Fosfat yang merupakan salah satu senyawa nutrien yang sangat penting di laut. Di perairan laut, fosfat berada dalam bentuk anorganik dan organik terlarut seta partikulat fosfat (Moriber, 1974 dalam Affan, 2010. Fosfat merupakan zat hara yang dibutuhkan untuk proses pertumbuhan dan metabolisme fitoplankton dan organisme laut lainnya dalam menentukan kesuburan perairan, kondisinya tidak stabil karena mudah mengalami proses pengikisan, pelapukan dan pengenceran. Distribusi fosfat dari daerah lepas pantai ke daerah pantai menunjukkan konsentrasi yang semakin tinggi menuju ke arah pantai. Thomas (1955) dalam Kadim et al. (2017), fosfor menjadi faktor pembatas yang sangat penting di perairan produktif dan tidak produktif, fosfor memainkan peranan penting dalam determinasi jumlah fitoplankton.

Berdasarkan hasil analisis, konsentrasi kandungan fosfat pada stasiun pengukuran berkisar $0,016-1,19 \mathrm{mg} / \mathrm{l}$. Nilai tersebut menandakan bahwa kandungan fosfat di perairan Depapre telah melebihi standar baku mutu air laut untuk biota laut sebagaimana dalam Keputusan Menteri Negara Lingkungan Hidup No. 51 tahun 2004, yaitu 0,015 $\mathrm{mg} / \mathrm{l}$. Kondisi tersebut dapat berbahaya bagi biota laut yang hidup dalam perairan Depapre dan bisa menyebabkan eutrofikasi. Menurut Anhwange (2012) bahwa tingkat maksimum fosfat yang disarankan untuk sungai dan perairan yang telah dilaporkan adalah $0,1 \mathrm{mg} / \mathrm{l}$. Perairan yang nilai fosfatnya lebih dari $0.1 \mathrm{mg} / \mathrm{l}$ sebagai perairan eutrof, dimana perairan ini sering terjadi blooming fitoplankton (Subarijanti, 2005 dalam Kadim et al., 2017). Selain itu, dari hasil analisis diperoleh bahwa stasiun 3 yang berjarak cukup jauh dari wilayah pesisir memiliki konsentrasi fosfat yang lebih rendah dibandingkan stasiun lainnya. Menurut Hutagalung dan Rozak (1997), pola sebaran yang menunjukkan konsentrasi yang lebih tinggi ke arah pantai ini disebabkan oleh dekatnya perairan dari sumber masukan fosfat dari daratan. Pengaruh daratan terhadap masukan fosfat ke perairan tersebut terlihat sangat besar.

Selain secara alami, sumber fosfat di perairan Depapre diduga berasal dari bersumber dari aktifitas manusia, seperti buangan limbah domestik, dan kegiatan lainnya serta limpahan air dari aktifitas pertanian masyarakat yang telah berlangsung dalam waktu yang lama, mengingat belum ada kawasan industri di sekitar lokasi penelitian. Menurut Moriber (1974) dalam Affan (2010) bahwa senyawa fosfat di perairan berasal dari sumber alami seperti erosi tanah, buangan dari hewan dan pelapukan tumbuhan. Konsentrasi meningkat dengan masuknya limbah domestik, industri dan pertanian atau perkebunan yang banyak mengandung fosfat, hancuran bahan organik dan mineral-mineral fosfat. 


\subsection{Nitrat $\left(\mathrm{NO}_{3}-\mathrm{N}\right)$}

Nitrat $\left(\mathrm{NO}_{3}-\mathrm{N}\right)$ adalah bentuk nitrogen utama di perairan alami. Nitrat merupakan salah satu nutrient senyawa yang penting dalam sintesa protein hewan dan tumbuhan. Konsentrasi nitrat yang tinggi di perairan dapat menstimulasi pertumbuhan dan perkembangan organisme perairan apabila didukung oleh ketersedian nutrient. Nitrifikasi yang merupakan proses oksidasi amonia menjadi nitrit dan nitrat adalah proses yang penting dalam siklus nitrogen dan berlangsung pada kondisi aerob. Oksidasi ammonia menjadi nitrit dilakukan oleh bakteri nitrosomonas, sedangkan oksidasi nitrit menjadi nitrat dilakukan oleh nitrobacter (Effendi, 2003).

Hasil analisis menunjukkan bahwa konsentrasi nitrat di stasiun pengukuran berkisar 0,009-0,54 $\mathrm{mg} / \mathrm{l}$. Konsentrasi nitrat yang diperoleh pada penelitian ini relatif hampir sama dengan perairan Papua lainnya, seperti yang dilaporkan oleh Silalahi (2017) bahwa konsentrasi nitrat di perairan Maruni Manokwari berkisar antara $0,1 \quad-0,8$ mg/l. Berdasarkan kandungan nitrat, perairan Depapre termasuk dalam perairan oligotrofik dengan kadar nitrat antara $0-1 \mathrm{mg} / \mathrm{l}$, Konsentrasi nitrat-nitrogen pada perairan alami hampir tidak pernah lebih dari 0,1 mg/l (Effendi, 2003).

Berdasarkan baku mutu kandungan nitrat di perairan dalam Keputusan Menteri Negara Lingkungan Hidup No. 51 tahun 2004, maka kandungan nitrat di perairan Depapre sebagian besar telah melebihi baku mutu, dimana standar baku mutu konsentrasi nitrat untuk biota laut adalah 0,008 mg/l. Hanya konsentrasi nitrat pada stasiun 2 yang masih memenuhi baku mutu untuk biota laut. Kondisi ini sangat membahayakan biota laut, karena menurut Effendi (2003) bahwa konsentrasi nitrat-nitrogen yang lebih dari $0,2 \mathrm{mg} / \mathrm{l}$ dapat mengakibatkan terjadinya eutrofikasi (pengayaan) perairan dan selanjutnya menstimulir pertumbuhan algae dan tumbuhan air secara pesat (blooming). Cukup tingginya konsentrasi nitrat di perairan depapre dapat disebabkan oleh masukan bahan organik yang tinggi dari aktivitas daratan yang dapat berupa erosi daratan, masukan limbah rumah tangga, limbah pertanian berupa sisa pemupukan dan lainnya yang terbawa ke perairan laut. Menurut Casali et al. (2007) bahwa dampak dari kegiatan pertanian akan menghasilkan limpasan, sedimen nitrat dan fosfat.

\subsection{Sulfida $\left(\mathrm{H}_{2} \mathrm{~S}\right)$}

Sulfida $\left(\mathrm{H}_{2} \mathrm{~S}\right)$ merupakan gas yang dihasil dari dekomposisi bahan organik yang dilakukan oleh bakteri anaerob dan merupakan gas yang sangat berbahaya bagi biota perairan serta menghasilkan bau yang tidak enak. Penyumbang terbentuknya hidrogen sulfida berbesar yaitu kawasan pemukiman, pelabuhan dan industri. Sulfida yang tidak terionisasi bersifat toksik terhadap kehidupan biota perairan.

Hasil analisis untuk konsentrasi sulfida pada perairan Depapre menunjukkan kandungan sulfida mempunyai nilai yang sama antar stasiun pengukuran yaitu $0,003 \mathrm{mg} / \mathrm{l}$ dan masih sesuai dengan standar baku mutu air laut untuk biota laut sebagaimana dalam Keputusan Menteri Negara Lingkungan Hidup No. 51 tahun 2004, yaitu $0,01 \mathrm{mg} / \mathrm{l}$. Rendahnya nilai tersebut menunjukkan masih sedikitnya limbah rumah tangga yang mengandung sulfida yang terbuang ke perairan laut. Selain itu, diduga juga karena rendahnya proses pembusukkan bahan-bahan organik yang mengandung belerang oleh bakteri anaerob dan juga sebagai hasil reduksi dengan kondisi anaerob terhadap sulfat oleh mikroorganisme (Triana, 2005 dalam Apriliana et al., 2014).

\subsection{Indeks Pencemaran Perairan Depapre}

Penentuan status mutu air pada perairan Depapre didasarkan atas metode indeks pencemaran. Suatu perairan dikatakan tercemar apabila tidak dapat digunakan sesuai dengan peruntukaannya secara normal. Hasil analisis nilai indeks pencemaran masing-masing stasiun pada penelitian ini selengkapnya disajikan pada Gambar 1.

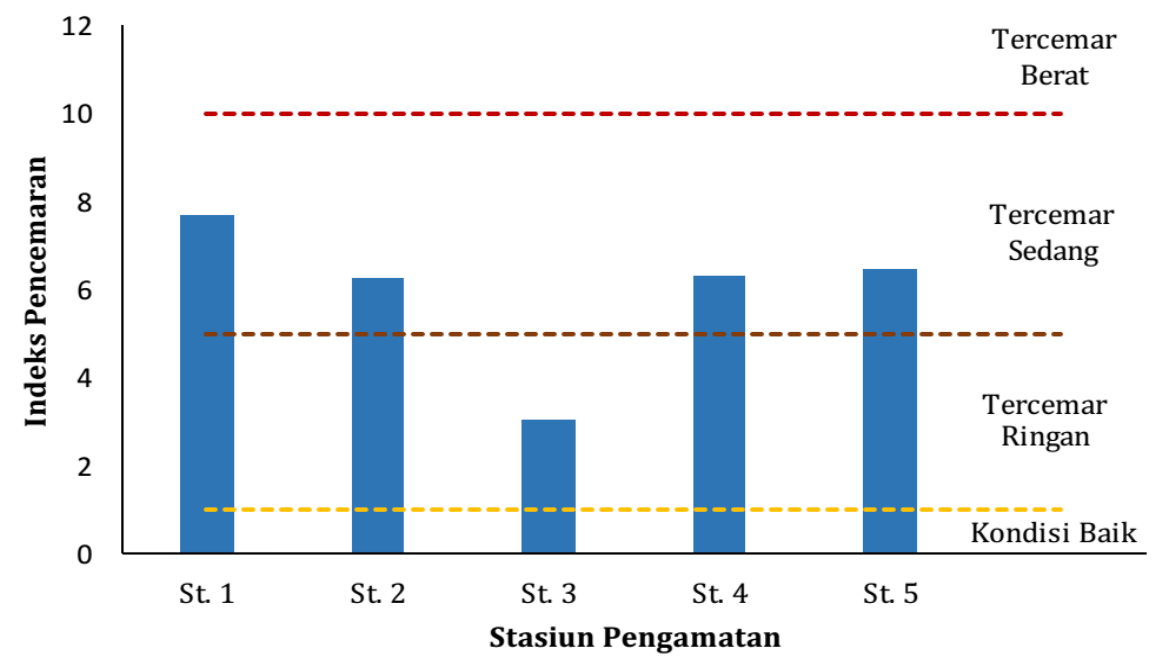

Gambar 1. Grafik indeks pencemaran perairan Depapre, Kabupaten Jayapura 
Berdasarkan hasil perhitungan indeks pencemaran (IP) pada Gambar 1, maka dapat diketahui bahwa semua stasiun pengamatan sudah keadaan tercemar ringan hingga sedang, dimana hanya stasiun 3 termasuk dalam kategori tercemar ringan. Perbedaan tersebut dapat saja disebabkan karena posisi stasiun 3 yang merupakan pulau yang tidak berpenghuni dan berlokasi cukup jauh dari wilayah pesisir atau daratan, sehingga dampak dari hasil aktifitas masyarakat di daratan sedikit berkurang. Hal ini dapat ditunjukkan dengan konsentrasi dari beberapa parameter lingkungan seperti ammonia total, fosfat dan nitrat memiliki konsentrasi yang lebih kecil dibandingkan stasiun lainnya, dimana 4 stasiun pengamatan lainnya merupakan daerah dengan tingkat aktifitas masyarakat yang cukup tinggi.

Pada kategori tercemar ringan diperoleh nilai indeks pencemaran 3,04 pada stasiun yang cukup jauh dari wilayah pesisir, sedangkan kategori tercemar pada wilayah pesisir diperoleh nilai indeks pencemaran antara 6,25 - 7,69. Sebagian besar parameter yang telah melampaui baku mutu untuk biota laut antara lain $\mathrm{pH}$, ammonia total, nitrat dan fosfat. Walaupun belum ada kejadian eutrofikasi yang dilaporkan hingga saat ini di perairan Distrik Depapre, kondisi tersebut sangat mengkhawatirkan karena ammonia total, nitrat dan fosfat merupakan parameter-parameter lingkungan yang mengandung zat hara dan nutrien yang apabila terdapat dalam konsentrasi yang tinggi dan bahkan terus meningkat di perairan laut maka akan menyebabkan terjadinya eutrofikasi (blooming) yang sangat berbahaya bagi biota laut lainnya.

\section{Kesimpulan}

Kondisi perairan Distrik Depapre berdasarkan hasil perhitungan indeks pencemaran tergolong dalam kategori tercemar ringan dan tercemar berat. Perairan Pulau Dua termasuk dalam kategori tercemar ringan, sedangkan perairan Pantai Harlem, Kampung Tablasupa, Kampung Depapre dan pelabuhan Depapre tergolong dalam kategori tercemar sedang. Parameter lingkungan yang masih sesuai dengan baku mutu untuk biota laut antara lain suhu, salinitas, DO, BOD 5 , sulfida dan kecerahan (kecuali perairan dekat muara sungai di Kampung Depapre), sedangkan parameter yang telah melampaui baku mutu antara lain $\mathrm{pH}$, ammonia total, fosfat dan nitrat. Peningkatan parameter-parameter yang telah melampaui batas maksimum baku mutu berasal dari sumber alami dan limbah domestik dari aktifitas masyarakat cukup tinggi.

\section{DAFTAR PUSTAKA}

Affan, J.M. 2010. Analisis potensi sumberdaya laut dan kualitas perairan berdasarkan parameter fisika dan kimia di pantai timur Kabupaten Bangka Tengan. Spektra, 10(2), 99-113.

Anhwange, B.A., Agbaji, E.B., and Gimba, E.C. 2012. Impact Assessment of Human Activities and Seasonal Variation on River Benue, within Makurdi Metropolis. Journal of Science and Technology, 2, 248-254.

Apriliana, R., Rudiyanti, S., dan Purnomo, P.W. 2014. Keanekaragaman jenis bakteri perairan dasar berdasarkan tipe tutupan permukaan perairan di Rawa Pening. Diponegoro Journal of Maquares, 3(2), 119-128.

Bonnin, E.P., Biddinger, E.J., and Botte, G.G. 2008. Effect of catalyst on electrolysis of ammonia efflents. Journal of Power Sources, 182, 284-290.

Casali, J.R., Gimenez, J., Diez, J., Álvarez Mozos, J., de Lersundi, D.V., Goni, M., Campo, M.A., Chahor, Y., Gastesi, R., and Lopez, J. 2010. Sediment production and water quality of watersheds with contrasting land use in Navarre (Spain). Agricultural Water Management, 97, 16831694.

Dahuri, R., Rais, J., Ginting, S.P., dan Sitepu, M.J. 1996. Pengelolaan Sumberdaya Wilayah Pesisir dan Lautan Secara Terpadu. Jakarta: Pradnya Paramita.

Damaianto, B., dan Masduqi, A. 2014. Indeks pencemaran air laut pantai utara Kabupaten Tuban dengan parameter logam. Jurnal Teknik Pomits, 13(1), 1-4.

Dojlido, J.R., and Best, G.A. 1993. Chemistry of Water and Water Polution. England: Ellis Horwood Ltd.

Erari, S.S., Mangimbulude, J., dan Lewerissa, K. 2012. Pencemaran organik di perairan pesisir Pantai Teluk Youtefa Kota Jayapura, Papua. Prosiding Seminar Nasional Kimia Unesa 2012, C327-C340. Surabaya, 25 Pebruari 2012.

Effendi, H. 2003. Telaah Kualitas Air bagi Pengelolaan Sumberdaya dan Lingkungan Perairan. Cetakan Kelima. Yogjakarta: Kanisius.

Gemilang, W.A., dan Kusumah, G. 2017. Status indeks pencemaran perairan kawasan mangrove berdasarkan penilaian fisika-kimia di pesisir Kecamatan Brebes Jawa Tengah. EnviroScienteae, 13(2), 171-180.

Gholizadeh, M.H., Melesse, A.M., and Reddi, L. 2016. A comprehensive review on water quality parameters estimation using remote sensing techniques. Sensors, 16(8), 1298.

Hamuna, B., Paulangan, Y.P., dan Dimara, L. 2015. Kajian suhu permukaan laut mengunakan data satelit AquaMODIS di perairan Jayapura, Papua. Depik, 4(3), 160167.

Hutabarat, S., dan Evans, S.M. 1984. Pengantar Oseanografi. Jakarta: Universitas Indonesia Press.

Hutagalung, H.P., dan Rozak, A. 1997. Penetuan Kadar Nitrat. Metode Analisis Air Laut, Sedimen dan Biota. Pusat Penelitian dan Pengembangan Oceanologi. Jakarta: Lembaga Ilmu Pengetahuan Indonesia (LIPI).

Kadim, M.K., Pasisingi, N., dan Paramata, A.R. 2017. Kajian kualitas perairan Teluk Gorontalo dengan menggunakan metode STORET. Depik, 6(3), 235-241.

Kementerian Negara Lingkungan Hidup. 2003. Keputusan Menteri Lingkungan Hidup Nomor 115 Tahun 2003 tentang Penetapan Status Mutu Air.

Kementerian Negara Lingkungan Hidup. 2004. Keputusan Menteri Negara Lingkungan Hidup Nomor 51 Tahun 2004 tentang Baku Mutu Air Laut. 
Hamuna, B., Tanjung, R.H.R, Suwito, Maury H.K., Alianto. (2018). Kajian Kualitas Air Laut dan Indeks Pencemaran Berdasarkan Parameter Fisika-Kimia Di Perairan Distrik Depapre, Jayapura. Jurnal IImu Lingkungan, 16(1), 35-43, doi:10.14710/jil.16.1.35-43

Kusumaningtyas, M.A., Bramawanto, R., Daulat, A., dan Pranowo, W.S. 2014. Kualitas perairan Natuna pada musim transisi. Depik. 3(1), 10-20.

Megawati, C., Yusuf, M., dan Maslukah, L. 2014. Sebaran kualitas perairan ditinjau dari zat hara, oksigen terlarut dan $\mathrm{pH}$ di perairan selatan Bali Bagian Selatan. Jurnal Oseanografi, 3(2), 142-150.

Nonji, A. 2005. Laut Nusantara. Jakarta: Penerbit Djambatan. Odum, E.P. 1971. Fundamental of Ecology. Philadelphia: W.B Sounders Company Ltd.

Pemerintah Republik Indonesia. 1999. Peraturan Pemerintah Republik Indonesia Nomor 19 Tahun 1999 Tentang Pengendalian Pencemaran dan/atau Pengrusakan Laut.

Salmin. 2005. Oksigen terlarut (DO) dan kebutuhan oksigen biologi (BOD) sebagai salah satu indikator untuk menentukan kualitas perairan. Oseana, 30(3), 21-26.

Silalahi, H.N., Manaf, M., dan Alianto. 2017. Status mutu kualitas air laut Pantai Maruni Kabupaten Manokwari. Jurnal Sumberdaya Akuatik Indopasifik, 1(1), 33-42.

Simanjuntak, M. 2009. Hubungan faktor lingkungan kimia, fisika terhadap distribusi plankton di perairan Belitung Timur, Bangka Belitung. Journal of Fisheries Sciences, 11(1), 31-45.

Widiadmoko, W. 2013. Pemantauan Kualitas Air Secara Fisika dan Kimia di Perairan Teluk Hurun. Bandar Lampung: Balai Besar Pengembangan Budidaya Laut (BBPBL) Lampung.

Yudo, S. 2010. Kondisi kualitas air Sungai Ciliwung di Wilayah DKI Jakarta ditinjau dari parameter organik, amoniak, fosfat, deterjen dan bakteri coli. Jurnal Akuakultur Indonesia, 6(1), 34-42. 